\title{
Colistin-resistant Klebsiella pneumoniae in Surgical Polytrauma Intensive Care Unit of Level-1 Trauma Center: First Case Series from Trauma Patients in India
}

\author{
Richa Aggarwal, Neha Rastogi', Purva Mathur', Kapil Dev Soni, Subodh Kumar, Amit Gupta, Sushma Sagar \\ Division of Trauma Surgery and Critical Care, 'Department of Laboratory Medicine, JPNA Trauma centre, AllMS, New Delhi, India
}

\section{Abstract}

Introduction: There have been isolated case reports and reports of outbreak of colistin-resistant Klebsiella from various parts of the world but only two from India and that too from oncology centers. We report cluster of colistin-resistant Klebsiella pneumonia bloodstream infection cases from our surgical trauma Intensive Care Unit. Methodology: The study was carried out in surgical ICU of Level-I trauma center. Retrospective analysis of all the five patients with CRK was done. Demographic data, antibiotic exposure throughout the hospital stay, hospital course, and clinical outcome were analyzed. Results: Out of 5 patients, 4 were young males (mean age of 23.5 years) without comorbidities and had undergone exploratory laparotomy following blunt trauma abdomen. 3 patients were chronic patients and had been on carbapenem and colistin 11-20 days before isolation whereas 2 patienst had isolation of CRK just within 7 days of admission. Out of the five patients, 3 patients survived and 2 had fatal outcome. Conclusions: CRK is an emerging and challenging pathogen in polytrauma victims . There was an outbreak of CRK in our ICU that could be contained with infection control measures.

Keywords: Colistin-resistant Klebsiella pneumonia, polytrauma, surgical Intensive Care Unit

\section{INTRODUCTION}

The isolation of multidrug-resistant organisms is increasing day by day in the Intensive Care Unit (ICU) settings and poses a great challenge in treating these patients. Carbapenem-resistant Enterobacteriaceae are widespread across various parts of the world and particularly carbapenem-resistant Klebsiella pneumoniae are quite common. ${ }^{[1]}$ Carbapenem-resistant Klebsiella constitute $92 \%$ of all carbapenem-resistant in United States. ${ }^{[2]}$ Even so, carbapenemase-producing Klebsiella are considered endemic in some areas. ${ }^{[3]}$ Colistimethate sodium is considered drug of choice and the only option available for treating these infections. However, now a days, there have been many isolated case reports and reports of outbreak of carbapenem and colistin-resistant Klebsiella (CRK) from various parts of the world. ${ }^{[4-7]}$ The notorious CRK are emerging pathogens in Indian subcontinent also and have been reported from an oncology center in eastern India ${ }^{[8]}$ and medical college in southern India. ${ }^{[9]}$ These case reports of infection were in immunocompromised patients. We report 5 cases of invasive

\begin{tabular}{|l|l|}
\hline \multicolumn{2}{|c|}{ Access this article online } \\
\hline Quick Response Code: & Website: \\
\hline & www.ijccm.org \\
\hline & \\
\hline
\end{tabular}

blood stream infections due to CRK in immunocompetent patients in our polytrauma ICU of Level-I trauma center in India. In April-June 2016, we had 5 cases of invasive blood stream infections due to CRK. Since incidence of CRK over last year in our hospital and ICU was 0 cases/month, this sudden increase in CRK infections was defined as an outbreak. Here, we describe the epidemioclinical profile, microbiological investigation, clinical outcome of those cases, and the various infection control practices undertaken to curb the outbreak. To the best of our knowledge, this is one of the initial reported CRK cases of blood stream infections in trauma victims.

Address for correspondence: Dr. Richa Aggarwal, Division of Trauma Surgery and Critical Care, JPNATC, AllMS, New Delhi - 110 029, India. E-mail: pathakricha@yahoo.co.in

This is an open access article distributed under the terms of the Creative Commons Attribution-NonCommercial-ShareAlike 3.0 License, which allows others to remix, tweak, and build upon the work non-commercially, as long as the author is credited and the new creations are licensed under the identical terms.

For reprints contact: reprints@medknow.com

How to cite this article: Aggarwal R, Rastogi N, Mathur P, Soni KD, Kumar S, Gupta A, et al. Colistin-Resistant Klebsiella pneumoniae in surgical polytrauma intensive care unit of Level-1 trauma center: First case series from trauma patients in india. Indian J Crit Care Med 2018;22:103-6. 


\section{Methodology}

The study was carried out in surgical ICU of Level-I trauma center in India. Retrospective analysis of all the five patients with CRK was done by medical records' review. Demographic data, antibiotic exposure throughout the hospital stay, hospital course, and clinical outcome were analyzed.

\section{Microbiological identification and antimicrobial testing}

The microbial identification of all Gram-negative bacterial isolates was done by VITEK 2 compact system (Biomerieux Ltd., France). The antimicrobial susceptibility testing of all Gram-negative isolates was done by the disc diffusion method on Mueller-Hinton agar according to the Clinical Laboratory Standards Institute (CLSI) guidelines. Escherichia coli ATCC 25922 was taken as control strain.

The following antimicrobials were tested: ampicillin $(10 \mu \mathrm{g})$, ampicillin/sulbactam $(10 / 10 \mu \mathrm{g})$, amoxycillin $(10 \mu \mathrm{g})$, ceftazidime $(30 \mu \mathrm{g})$, ceftazidime/clavulanic acid $(30 / 10 \mu \mathrm{g})$, cefotaxime $(30 \mu \mathrm{g})$, ceftriaxone $(30 \mu \mathrm{g})$, cefoperazone $(30 \mu \mathrm{g})$, cefoxitin $(30 \mu \mathrm{g})$, cefpodoxime $(30 \mu \mathrm{g})$, cefepime $(30 \mu \mathrm{g})$, aztreonam $(30 \mu \mathrm{g})$, piperacillin $(100 \mu \mathrm{g})$, piperacillin/tazobactam $(100 / 10 \mu \mathrm{g})$, ticarcillin/clavulanic acid $(75 / 10 \mu \mathrm{g})$, cefoperazone/sulbactam $(75 / 30 \mu \mathrm{g})$, cefepime/tazobactam $(30 / 10 \mu \mathrm{g})$, ceftriaxone/sulbactam $(30 / 15 \mu \mathrm{g})$, imipenem $(10 \mu \mathrm{g})$, meropenem $(10 \mu \mathrm{g})$, ertapenem $(10 \mu \mathrm{g})$, amikacin $(30 \mu \mathrm{g})$, gentamicin $(10 \mu \mathrm{g})$, netilmicin $(30 \mu \mathrm{g})$, ciprofloxacin $(5 \mu \mathrm{g})$, levofloxacin $(5 \mu \mathrm{g})$, tigecycline $(15 \mu \mathrm{g})$, polymyxin B (300 U), colistin $(10 \mu \mathrm{g})$, and chloramphenicol $(30 \mu \mathrm{g})$.

Colistin susceptibility was done by both disc diffusion testing and VITEK 2 compact for all isolates. For bacterial isolates showing resistant minimal inhibitory concentration (MIC) cutoff values, further testing was done using $\mathrm{E}$ test in accordance with CLSI guidelines. There is no available colistin breakpoint for Enterobacteriaceae as per CLSI guideline, so EUCAST breakpoints were followed ( $\leq 2 ; \mathrm{R}>2$ ). Bacterial isolates were considered to be pandrug resistant (PDR) if isolates were resistant to all classes of antimicrobial.

\section{RESULTS}

The isolates were isolated in a span of 42 days in our ICU, the first being on April 23, 2016 and last on June 05, 16. All the patients were admitted concurrently or subsequently in the same cubicle of the ICU. The demographic profile of the patients is given in Table 1 . Out of 5 patients, 4 were young males (mean age of 23.5 years) without comorbidities and had undergone exploratory laparotomy following blunt trauma abdomen. All had invasive blood stream infection due to CRK and no isolation from any other site. One patient was 55 years old with coexisting hypertension and diabetes, had chest trauma with head injury, and he had concurrent isolation of CRK from blood, bronchoalveolar lavage, and urine. Patient no. 2 and 3 were referred from outside hospital where they had stayed for 7 and 8 days, respectively.

\section{Timing of isolation}

Patient no. 1, 2, and 3 were chronic patients and had isolation of bacteria 25,57 , and 13 days, respectively, after ICU admission and had been on carbapenem and colistin 11-20 days before isolation whereas patient no. 4 and 5 had isolation of CRK just within 7 days of admission. The mean length of colistin use was 12.4 days.

\section{Antibiotics after isolation}

After the isolation of Klebsiella, colistin was stopped in all the patients. As patient no. 1, 3, and 4 [mentioned in Table 2] had severe abdominal sepsis and were in septic shock at the time of isolation, tigecycline was added. The extensive search for the source was done and surveillance cultures were sent from all possible sites and drains in all cases. Repeated peritoneal washings were done for patient 1, 3, and 4 .

Only patient no. 2 had positive cultures for resistant Klebsiella from BAL and urine. He was continued on meropenem only. Patient no. 5 was clinically stable and had no exposure to colistin; he was continued on netilmycin.

All the patients had subsequent microclearance with cultures coming negative and subsequently started growing Klebsiella and Acinetobacter sensitive to colistin.

\begin{tabular}{|c|c|c|c|c|c|c|c|c|}
\hline Patient & $\begin{array}{c}\text { Age } \\
\text { (years) }\end{array}$ & Sex & Diagnosis & Comorbidities & $\begin{array}{l}\text { Referred } \\
\text { case }\end{array}$ & $\begin{array}{c}\text { Days of } \\
\text { previous } \\
\text { hospitalization }\end{array}$ & $\begin{array}{l}\text { Date of } \\
\text { admission }\end{array}$ & $\begin{array}{l}\text { Operative procedure } \\
\text { done }\end{array}$ \\
\hline 1 & 22 & Male & $\begin{array}{l}\text { Duodenal blowout and } \\
\text { biliary peritonitis }\end{array}$ & No & No & 82 & April 3, 2016 & $\begin{array}{l}\text { Laprotomy with } \\
\text { peritoneal wash with } \\
\text { right intercostal drain }\end{array}$ \\
\hline 2 & 55 & Male & $\begin{array}{l}\text { RTI with frontotemporal } \\
\text { contusion with } 2^{\text {nd }}-7^{\text {th }} \\
\text { rib fracture }\end{array}$ & HTN DM & Yes & 7 & April 4, 2016 & None \\
\hline 3 & 28 & Male & $\begin{array}{l}\text { RTI with liver } \\
\text { laceration }\end{array}$ & No & Yes & 8 & April 10, 2016 & $\begin{array}{l}\text { Laparotomy + hepatic } \\
\text { packing }\end{array}$ \\
\hline 4 & 16 & Male & $\begin{array}{l}\text { RTI with Grade V liver } \\
\text { laceration }\end{array}$ & No & No & 0 & April 28, 2016 & $\begin{array}{l}\text { Laparotomy + peritoneal } \\
\text { wash }\end{array}$ \\
\hline 5 & 28 & Male & $\begin{array}{l}\text { BTA with fracture } \\
\text { pelvis with bilateral } \\
\text { facial fracture }\end{array}$ & No & No & 0 & May 6, 2016 & $\begin{array}{l}\text { Laparotomy + internal } \\
\text { artery ligation }\end{array}$ \\
\hline
\end{tabular}


Aggarwal, et al.: Colistin-resistant klebsiella pneumonia in trauma ICU

\begin{tabular}{|c|c|c|c|c|c|c|c|c|c|c|}
\hline \multirow[t]{2}{*}{ Patient } & \multirow{2}{*}{$\begin{array}{l}\text { Site of } \\
\text { isolate }\end{array}$} & \multirow{2}{*}{$\begin{array}{l}\text { Date of } \\
\text { isolation }\end{array}$} & \multirow{2}{*}{$\begin{array}{l}\text { Days in } \\
\text { ICU before } \\
\text { isolation }\end{array}$} & \multirow{2}{*}{$\begin{array}{l}\text { Days of colistin/ } \\
\text { carbapenem } \\
\text { prior use }\end{array}$} & \multicolumn{2}{|l|}{ MIC } & \multirow{2}{*}{$\begin{array}{l}\text { Treatment } \\
\text { given }\end{array}$} & \multirow[t]{2}{*}{ Microclearance } & \multirow{2}{*}{$\begin{array}{l}\text { Length of } \\
\text { stay in ICU } \\
\text { (days) }\end{array}$} & \multirow{2}{*}{ Outcome } \\
\hline & & & & & Carbapenem & Colistin & & & & \\
\hline 1 & Blood & $\begin{array}{l}\text { April 27, } \\
2016\end{array}$ & 25 & 20 & 64 & $>16$ & $\begin{array}{l}\text { Cefepime }+ \\
\text { tazobactam } \\
\text { Tigecycline }\end{array}$ & Yes & 39 & Died \\
\hline 2 & $\begin{array}{l}\text { Blood, also in } \\
\text { BAL, urine }\end{array}$ & June 5, 2016 & 57 & 26 & 8 & $>16$ & $\begin{array}{l}\text { Cefepime }+ \\
\text { tazobactam }\end{array}$ & Yes & 84 & Died \\
\hline 3 & Blood & $\begin{array}{l}\text { April 23, } \\
2016\end{array}$ & 13 & 11 & 32 & $\geq 16$ & $\begin{array}{l}\text { Cefepime }+ \\
\text { tazobactam } \\
\text { Tigecycline }\end{array}$ & Yes & 65 & Survived \\
\hline 4 & Blood & May 6, 2016 & 7 & 5 & 32 & $\geq 16$ & Tigecycline & Yes & 55 & Survived \\
\hline 5 & Blood & May 13, 2016 & 6 & 0 & 32 & $\geq 16$ & Netilmycin & Yes & 9 & Survived \\
\hline
\end{tabular}

BAL: Bronchoalveolar lavage; ICU: Intensive Care Unit; MIC: Minimum inhibitory concentration

\section{Outcome}

Out of the five patients, 3 patients (no. 3, 4, 5) survived and 2 had fatal outcome. Patient no. 1 had multiple intestinal fistulas and biliary peritonitis and patient no. 2 was a chronic patient with comorbidities and head injury who did not improve.

\section{Molecular analysis of the isolates}

A total of 7 isolates are obtained from these cases. All isolates were resistant to colistin. All isolates had MIC $>16 \mu \mathrm{g} / \mathrm{ml}$. Molecular analysis revealed isolates belong to 2 sequence types -ST 11 and ST 14. These isolates had 3 novel fos A variants. They are negative for mcr-1 gene. Chromosomal-mediated resistance was observed in these strains with mutation in 5 genes.

\section{Discussion}

The emergence and isolation of pandrug-resistant Enterobacteriaceae is increasing and posing a great challenge to clinicians. Carbapenem resistance in Klebsiella has been increasing and is as high as $44 \%$ in India. ${ }^{[9]}$ The only drug available for these infections is colistin but rampant use of colistin has led to increased resistance to this drug. ${ }^{[10]}$ Case reports and outbreaks have been reported from around the world but few cases only from India. It is difficult to tell in Indian scenario as such cases are highly underreported.

We report five cases of multidrug-resistant Klebsiella, resistant to colistin. Sensitivity testing for fosfomycin was not done. Goel et al..$^{[8]}$ described a series of CRK infection colonization from an oncology center in eastern part of India. The number of patients with positive blood culture was $10.62 \%$ of these patients were receiving colistin before isolation as in our case series. The isolates in their series showed intermediate to good susceptibility to tigecycline. Another reporting ${ }^{[9]}$ of CRK has been done from India and all the strains isolated were sensitive to tigecycline.

Ghafur et al. ${ }^{[11]}$ reported isolation of PDR Gram-negative bacteria from 13 patients in a tertiary care oncology and stem cell transplant center in India, but they had reported about all the Gram-negative bacteria and not only Klebsiella. They had five patients infected with resistant Klebsiella and were treated with colistin-based regimens with or without combination with carbapenem and tigecycline. However, in our series, colistin was stopped in all cases, and patients with abdominal sepsis were taken on tigecycline.

All the above case reports are from oncology center where patients are immunocompromised. Ours is a trauma center and we have young immunocompetent patients, so isolation of CRK strains is a matter of huge concern.

Isolated reports of isolation of Klebsiella resistant to colistin have emerged from Greece, Italy, and South Korea. Three different clones for CRK were detected in Italy ${ }^{[12]}$ and South Korea. ${ }^{[5]}$

The risk factors for acquisition of KPC-producing organisms have been cited in various studies. These include prolonged ICU stay, hospitalization, poor functional status, immunosuppression, and posttransplant surgery. ${ }^{[13]}$ This seems true for developing colistin resistance infection also. Colistin resistance is mainly mediated by modification of lipopolysaccharide moiety of bacterial wall. ${ }^{[14]}$ It can occur de novo because of use of colistin or can be transmitted horizontally from one patient to another. The isolation of the colistin-resistant organisms from the same cubicle in ICU and in the same time frame suggested horizontal spread of resistant organisms.

\section{Infection control measures taken}

The isolation of the colistin-resistant organisms from the same cubicle in ICU and in the same time frame suggested horizontal spread of resistant organisms. After 3 consecutive cases, detailed systematic and rigorous hospital infection control practices were undertaken to prevent further spread. We have an intensive, automated ongoing hospital-acquired infection surveillance network and hand hygiene monitoring system. Initially, the infected patient was isolated by means of physical barrier/curtain stand within the cubicle. Each and every cubicle was disinfected by fogging using hydrogen peroxide. Intensive terminal cleaning of cubicles, bed rails, bedside objects was done with quaternary ammonium 
compounds. Thorough cleaning of curtains, beddings, and linen was done using appropriate heat disinfection. Hand hygiene with water or alcohol-based hand rub was intensively reinforced and usage of personal protection equipment was encouraged.

All our patients had microclearance though we used different combination of antibiotics in all. We resorted to combination of cefepime-tazobactam and tigecycline in patients with abdominal sepsis, i.e., patients 1, 3, and 4. Patient no. 3 and 4 responded well but patient no. 1 died because of irreversible abdominal biliary sepsis due to multiple intestinal fistulae. Patient no. 1 and 3 were cocolonized with Acinetobacter baumanni, so we had to give colistin later on in these patients. Various treatment modalities have been suggested for the treatment of colistin- and carbapenem-resistant Klebsiella infection which include colistin-based regimens such as combination of high-dose tigecycline with colistin ${ }^{[15]}$ and colistin with double carbapenem regimen. ${ }^{[16,17]}$

\section{ConcLusion}

CRK is an emerging and challenging pathogen in polytrauma victims in whom several injuries and various surgical interventions lead to prolonged intrahospital stay along with exposure and dependence on various invasive medical devices and use of multiple antibiotics as a prophylaxis or therapeutic regimen. There was an outbreak of CRK in our ICU that was contained with appropriate infection control practices.

\section{Financial support and sponsorship}

Nil.

\section{Conflicts of interest}

There are no conflicts of interest.

\section{ReFERENCES}

1. Nordmann P, Naas T, Poirel L. Global spread of carbapenemase-producing Enterobacteriaceae. Emerg Infect Dis 2011;17:1791-8.

2. Centers for Disease Control and Prevention (CDC). Guidance for control of infections with carbapenem-resistant or carbapenemase-producing Enterobacteriaceae in acute care facilities. MMWR Morb Mortal Wkly Rep 2009;58:256-60.

3. Kalem F, Ergun A, Ertuğrul Ö, Özçimen S, Şimşek H, Arslan U, et al. Colistin resistance in carbapenem-resistant Klebsiella pneumoniae strains. Biomed Res 2016;27:368-72.

4. Antoniadou A, Kontopidou F, Poulakou G, Koratzanis E, Galani I,
Papadomichelakis E, et al. Colistin-resistant isolates of Klebsiella pneumoniae emerging in Intensive Care Unit patients: First report of a multiclonal cluster. J Antimicrob Chemother 2007;59:786-90.

5. Suh JY, Son JS, Chung DR, Peck KR, Ko KS, Song JH, et al. Nonclonal emergence of colistin-resistant Klebsiella pneumoniae isolates from blood samples in South Korea. Antimicrob Agents Chemother 2010;54:560-2.

6. Zarkotou O, Pournaras S, Voulgari E, Chrysos G, Prekates A, Voutsinas D, et al. Risk factors and outcomes associated with acquisition of colistin-resistant KPC-producing Klebsiella pneumoniae: A matched case-control study. J Clin Microbiol 2010;48:2271-4.

7. Marchaim D, Chopra T, Pogue JM, Perez F, Hujer AM, Rudin S, et al. Outbreak of colistin-resistant, Carbapenem-resistant Klebsiella pneumoniae in metropolitan Detroit, Michigan. Antimicrob Agents Chemother 2011;55:593-9.

8. Goel G, Hmar L, Sarkar De M, Bhattacharya S, Chandy M. Colistin-resistant Klebsiella pneumoniae: Report of a cluster of 24 cases from a new oncology center in Eastern India. Infect Control Hosp Epidemiol 2014;35:1076-7.

9. Pragasam AK, Shankar C, Veeraraghavan B, Biswas I, Nabarro LE, Inbanathan FY, et al. Molecular mechanisms of colistin resistance in Klebsiella pneumoniae causing bacteremia from India-A first report. Front Microbiol 2016;7:2135.

10. Kontopidou F, Plachouras D, Papadomichelakis E, Koukos G, Galani I, Poulakou $\mathrm{G}$, et al. Colonization and infection by colistin-resistant gram-negative bacteria in a cohort of critically ill patients. Clin Microbiol Infect 2011;17:E9-11.

11. Ghafur A, Vidyalakshmi PR, Murali A, Priyadarshini K, Thirunarayan MA. Emergence of Pan-drug resistance amongst gram negative bacteria! The first case series from India. J Microbiol Infect Dis 2014;4:86-91.

12. Mammina C, Bonura C, Di Bernardo F, Aleo A, Fasciana T, Sodano C, et al. Ongoing spread of colistin-resistant Klebsiella pneumoniae in different wards of an acute general hospital, Italy, June to December 2011. Euro Surveill 2012;17. pii: 20248.

13. Schwaber MJ, Klarfeld-Lidji S, Navon-Venezia S, Schwartz D, Leavitt A, Carmeli Y, et al. Predictors of carbapenem-resistant Klebsiella pneumoniae acquisition among hospitalized adults and effect of acquisition on mortality. Antimicrob Agents Chemother 2008;52:1028-33.

14. Falagas ME, Rafailidis PI, Matthaiou DK. Resistance to polymyxins: Mechanisms, frequency and treatment options. Drug Resist Updat 2010;13:132-8.

15. Humphries RM, Kelesidis T, Dien Bard J, Ward KW, Bhattacharya D, Lewinski MA, et al. Successful treatment of pan-resistant Klebsiella pneumoniae pneumonia and bacteraemia with a combination of high-dose tigecycline and colistin. J Med Microbiol 2010;59:1383-6.

16. Oliva A, Mascellino MT, Cipolla A, D’Abramo A, De Rosa A, Savinelli S, et al. Therapeutic strategy for pandrug-resistant Klebsiella pneumoniae severe infections: Short-course treatment with colistin increases the in vivo and in vitro activity of double carbapenem regimen. Int J Infect Dis 2015;33:132-4.

17. Oliva A, D'Abramo A, D'Agostino C, Iannetta M, Mascellino MT, Gallinelli $\mathrm{C}$, et al. Synergistic activity and effectiveness of a double-carbapenem regimen in pandrug-resistant Klebsiella pneumoniae bloodstream infections. J Antimicrob Chemother 2014;69:1718-20. 